life of this great man; his early promise, even from his birth (for we are told that he was the seventh son), a portent of success. Truly this seventh son was one of whom not only his family were proud, but his country revered, and who won by steadfastness of purpose and uprightness of action the admiration of the whole civilized world. Doubtless this was largely enhanced by his discovery of the anæsthetic powers of chloroform, but this very discovery was but the result of his dogged determination, a direct result of his character.

The discovery of chloroform anæsthesia occupies but a tithe of the book, and this includes a brief, concise, but clear history of anæsthesia. It is short, but, great though its importance it truly forms but a striking epoch in the busy life. Of the greatest interest is the chapter on the fight for anæsthesia, and his wit was no less useful than his learning in this fight of prejudice, ignorance, and bigotry against a new and glorious fact. Witness his famous parody on the Dublin letter, p. I2I.

His antiquarian researches, his kindness, generosity, and hospitality are all faithfully portrayed. It was his custom, we are told, to go his round without a list of patients, trusting only to his memory. In even a brief review it would be obviously wrong not to allude to that great achievement of his, the elevation of the practice of midwifery to a level with that of its sister arts and sciences. He worked for this, and he saw his point gained. What greater reward could such a man desire?

Finally, we only wish to compliment the author on his production, and advise our readers to secure this also for early perusal.

NOTICE.

\title{
AN INTERNATIONAL DIRECTORY OF LARYNGOLOGISTS AND OTOLOGISTS.
}

THE Managing Sub-Editor will be glad to receive the names and addresses of all Laryngologists, Rhinologists, and Otologists for this Directory.

The Directory will be published June, I898. It will contain the names and addresses of all the specialists obtainable (already several thousand).

Will be published under the auspices of the Journal. Price and date of publication will be issued later.

Address : Managing Sub-Editor, care of REBman \& Co., II, Adam Street, London, W.C., England. 


\section{NEW INSTRUMENT.}

Dr. W. MCNeill Whistler brings to our notice a laryngeal forceps designed by him, which he showed some time since at a meeting of the British Laryngological, Rhinological, and Otological Association. The terminal extremity is rotatory, and so may be applied at any angle to the growth requiring removal.

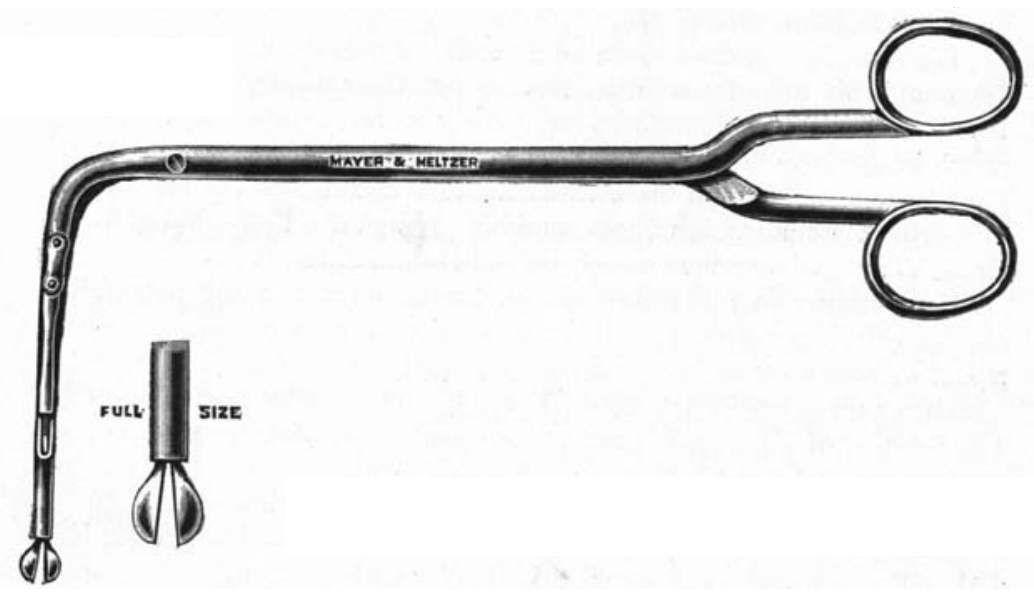

The proximal end or handle of the forceps works always in a zertical direction, this being a very distinct advantage over the ordinary lateral forceps in operating upon growths with central attachment. The shaft of the instrument, playing through a canula, is readily deflected so as not to obstruct the view in operating.

The accompanying woodcut illustrates the action of the forceps, the makers of which are Messrs. Mayer \& Meltzer, Great Portland Street, London. 


\section{INDEX T0 VOL. XIII., I898.}

A.

Abductor paralysis 219, 289, 522

Abscess-

cerebral $158,162,186,217,316,411$, $416,418,573$

epiglottic 622,623

extra-dural 160, 218, 316

laryngeal 5 II, 547

mastoid $218,456,486,590$

nasal $234,55^{2}$

naso-pharyngeal 513

occipital 592

crbital 559

otitic 503

peri-auricular 553

pneumonic 76

retro-pharyngeal $306,554,593$

sub-dural 507, 545

velar 623

Acetylene lamp 145

Adeno-carcinoma of the nose 95,602

Adeno-epithelioma of auricle $\mathbf{6 2 2}$

Adenoids-

and hypertrophied tonsils 245

and laryngeal stridor, 303, 308, 309

complications following extirpation of 276

in adults 512,547

occurrence of, in India 405

recurrence of 563

removal of, for otitis media 283,400

Adenoiditis $52 \mathrm{r}$

Adhesion of soft palate to pharynx 62, 296

Agroraphobia and Ménière's symptom. 622

Air-passages-

chronic catarrh of 206

fever after operation in 209

foreign bodies in $157,255,409,57^{\circ}$

pseudo-membranous affections of 409

stenosis of 410,412
Alcohol spray for laryngeal papilloma 610,612

Amaurosis following intra-nasal operntion 95

Anæsthesia, local, for operation- on tympanum 623

Anresthetics-

administration of, through a tracheai wound 96

chloroform 382,409

cocaine 90

eucaine 96

holocaine 252

orthoform 156, 157, 239

Anatomy of-

cthmoilal cells 554

tympanic antrum $16 \mathrm{r}, 230$

sub-glottic region 553

Aneurysm, aortic 75

Angina -

diphtheroid 240

epiglottic (222

Ludwig's 269

Angriumata of -

larynx 154

nose 245

tonsil 243

Antistreptococcic serum for mastoid disease 261

Antitoxin in-.

diphtheria 92, 304

lupus 504

ozxena 379

Antitoxin poisoning 305

Antral empyema-

in an infant 153

Luc's operative treatment of $55^{\circ}$

of long standing is $\mathbf{I}$

tubercular 153

Antrectomy for otiti media 103. 524

Antro-tympanic disease, complicated 2 rs

Antrum of Highmore--

catarrh of 368 
Antrum of Highmore operation on 177

pathology of 205

Antrum, tympanic, anatomy of 161,230 Aphonia 73

", atonic 100

, hysterical 74, I 55

Appointments 54, 105, 474

Arcus glosso-palatini, perforations in 206

Arsenious acid, treatment of malignant tumours with $62 \mathrm{I}$

Arytenoids, hypertrophy of 302

Asepsis in otology and laryngology $\mathbf{5 2 1}$

Atresia, naso-pharyngeal, operation for 250

Attic, cholesteatoma of 103

Attic cleft 557

Auditory cortical centre, pathology of 373

Aural affections 2 I 7

,, catarrh 364,396

,, exostoses 383

,, herpes 5 I I

" origin of cerebral tumours $\mathrm{IO2}$

,, polypus 206

," pyæmia, complications of 216

,' suppuration 217,418

"'vertigo 4I4

Auricle-

disease peculiar to 596

fissure of the 365

perichondritis of 397

tumours of the $6 \mathbf{2 2}$

ulceration of, syphilitic 160,215

Autoscopy 35I

B.

Bacteriology ofangina 240

diphtheria $304,466,562$

normal nose 124,248

pharyngitis 56

rhinitis 493,516

suppurative otitis media 502

tonsillitis $\mathbf{5 5 4}$

Baratoux's electrical laryngo-phantom 233

Bezold's mastoiditis 3 I 6

Bougies, use of, in ear diseases 260

Bronchoscopy 5 I9

Bronchus, foreign bodies in 518

Buccolingual leucoplasia 623

Bulbar paralysis 561

Bulla ethmoidalis 74

c.

Calculus, salivary 242

Cancer-

epiglottic 184,313
Cancer (continued) -

laryngeal 99, 209, 350, 519, 553

laryngectomy for 409

lingual 184

of maxillary sinus 330, 332, 333

pharyngeal 306

sub-glottic 143

tonsillar 242

Caries of

petrous bone 508

sphenoid 515

temporal $262,507,508,545$

Catarrh-

aural $364,396,598$

broncho-nasal 244

of maxillary sinus 368

pharyngeal, curettage for $\mathbf{6 2 2}$

Catheterization of Eustachian tubes 458

Cerebral abscess $158,162,217,416,418$

Cerebral symptoms with otitis 162,418 , 545

Cerebro-spinal fluid from ear 214

Children-

adenoids and hypertrophied tonsils 245

antral empyema 153

of deaf-mute parents 556

intubation $98,147,211,554$

laryngoscopy 278

naso-pharyngeal catarrh 606

otorrhoea 454

pharyngeal tuberculosis 243

scarlet fever, with complications $3 \mathbf{I} 7$, 516

sub-dural abscess 545

sudden death 210

tracheotomy $570,61 \mathrm{r}, 6 \mathrm{r} 5$

tympanitis, acute 395

Chloroform in-

adenoid operations 382

operations for laryngeal obstruction 409

Cholesteatoma 103, 149, 262, 364, 389, $393,502,573$

Chromic acid-

coating a probe-tip with 544

for intranasal synæechiæ 554

Cirrhosis, alcoholic 149

Cocaine anæsthesia 90

Colour hearing i 58

Condylomata of the ear 560

Cortical auditory centre $\mathbf{2 5 7}$

Croup, intubation for 554

Curetting for removal of sub-glottic

Cystfibroma $25^{2}$

cerebral $25^{\circ}$

epiglottic 65, 211, 299, $35^{8}$

frontal sinus 207

intralaryngeal 74

maxillary $59 \mathrm{r}$

nasal $272,35^{8}, 55^{2}$

thyroidal IOI

thyro-hyoid 67 
D.

Deaf-mutes -

defects of hearing in 395

singing lessons for 624

Deaf-mutism 212, 214, 315, $55^{6}$

Deafness-

catarrhal 598

following mumps 317

from meningitis 556

from influenza 556

hysterical 281, 621

massage in 260

sclerotic 77

Deviation of septum $55^{8,622}$

Diagnosis-

cases for $472,505,592$

of aural affections 217

of perforation of membrana tympani 214

Diphtheria-

antitoxin treatment of 92,304, 593

, for, dosage of 305

,iit for, immunization with 562

bacillus of, vitality of 305

$$
\text { for } 466
$$

Neisser's diagnostic stain

bacteriology of 562

heilserum for 203

relation to, of fibrinous rhinitis 492

slow pulse following 305

statistics of 305

Diphtheritic infection 91

$$
\text { , paralysis } 5 \text { or }
$$

," stomatitis 243

Diphtheroid angina 240

Diplacusis-

in Rinné's test 215

binauricularis echoica $4 \mathbf{I} 4$

monaural I 59

Dumbness, congenital 212

Dyslalia, sigmatic 349, 353

Dysphagia-

treatment of, with orthoform 199 losis 460

Dysphonia, relief of, by the galvanic current 597

Dyspnœa-

from influenza 387

spasmodic $3 \mathbf{I I}$

E.

Far -

condylomata of the 560

disease of, following whooping cough 258

disease of, following influenza 103

" special incidence of 590

", suppurative 448
Ear (continued) -

effects on, of compressed air 259

" of intracranial pressure 416

, of molten iron $55^{6}$

epithelioma of the 560,572

foreign body in 388,420

herpes of $54^{6}$

malformation of 396

sclerosis of 554

Ear-trumpets 376

Empyema-

antral, Luc's method of operating for $55^{\circ}$

antral, Stetter's treatment of 59 I

ethmoidal 74

frontal $75,207,301,307,593$

mastoidal $45^{2}$

maxillary $15 \mathrm{I}, 153,18 \mathrm{I}, 37 \mathrm{O}, 39 \mathrm{I}$

nasal 149

Endorhinitis, atrophic 246

Enuresis nocturna 75

Epiglottis-

abscess on 622,623

cyst in $65,211,299,35^{8}$

epithelioma of 467

pendulous 468

polypus of 210

tubercular 356

tumours of 133

ulceration of 544

Epileptiform attacks 354 ," due to nasal obstruction 564

Epithelioma of -

arytenoid region 199

ear $342,560,572$

epiglottis 467

larynx 29I, 57 I

maxillary sinus 325

pharynx 447

septum 509

uvula 183

vocal cord I $85,254,291,506$

Errata 54, 232, 256, 425, 526

Erysimum for laryngitis 253

Ethmoidal cells-

anatomy of 554

suppuration of 559,593

Ethmoidal disease 505

$$
\text { , sinusitis } 5 \text { 10, } 546
$$

Eustachian tube-

catheterization of 458

diseases of, treated with the bougie 260

Exanthemata in relation to aural suppuration 14

Exostosis of -

external auditory canal $33^{8}, 3^{8} 3$

$$
\text { of } 414
$$

frontal sinus 297 
viii.

Index.

Extra-dural suppuration in sigmoid fossa 448

F.

Face- $\quad$ lupus of 398 malformities and deformities of the 202

Facial nerverelation of tympanic antrum to 232 in relation to velar paralysis 616

Facial paralysis 218, 262, 502, 623

Fauces-

patches on 133

tuberculosis of 473

Fibromata of-

base of the skull 369,388

naso-pharynx 388

sub-glottis 252

vocal cord 358,468

Fistula, cerebral 4I I

Foreign bodies in-

air passages 409, 4I3, 570

bronchus 518

cheek 242

ear $258,388,420$

larynx 388,545

nose $153,207,208,617$

naso-pharynx 284

œesophagus 315

sub-glottic space 509

trachea 570

Fossa-

cranial, perforation into 207

middle cranial, in relation to tympanic antrum $23 I$

sigmoid, extra-dural suppuration in 448

supratonsillar, and its affections 165 , 179

Fracture of -

cartilage of external ear 262

" nose 496

Frontal sinus disease 139

Furuncles followed by peri-auricular abscess 553

G.

"Giant cells," origin and nature of 285

"Globi," origin and nature of 285

Glossitis-

acute 153

papillary 243,59

tuberculosa 243

Glottis-

closure of 256

cedema of 3 II

Goitre-

operation for 100,571

, followed by fever 213
Goître (continued) -

series of operations for $57 \mathrm{I}$

Graves's disease-

acute case of $3^{15}$

surgical treatment of 257

thyroidectomy for 213

Growth, lobulated, below anterior commissure $55^{8}$

Gullet, removal of fish-hook from 290

Gumma of nose 298

H.

Hæmatoma of nasal septum $55^{2}$

Hæmophilia, the nares and pharynx in a case of 247

Hæmorrhage, laryngeal I49, 253

Hæmorrhagic myringitis 364

,, septicæmia 3 I7

Hremostatic, gelatine as a 244

Hay fever 207

Headache-

caused by a centipede in the nose 543

new treatment of 407

Hearing, disturbances of 617

Herpes of the ear 546

Hoarseness, treatment of singers and speakers for 569

Holocaine in oto-laryngology 252

Hydrorrhœea, nasal 137, 239, 500

Hyoid, median osteotomy of ${ }^{5} 6$

Hypertrophy of -

arytenoids 302

interarytenoid fold 295

tonsil I35, 242, 405

Hypnotism in nasal stenosis $37 \mathbf{I}$

Hysteria, car manifestations in 509, 546

Hysterical aphonia 155

,$\quad$ deafness $28 \mathrm{I}, 62 \mathrm{I}$

\section{I.}

Infants-

croup 554

dysphagia 473

empyema 153

inspiratory stridor 568

meningitis 592

osteomyelitis, acute 204

osteo-periostisis of maxilla and orbit 370

paralysis 545

respiratory stridor 134,303

retropharyngeal abscess 554

sudden death 210

Inflammations 88

Influenza and-

dyspncea 387

ear complications 103,556

retropharyngeal abscess 593 
Instruments for cleansing mastoid 198 ," sterilizing of 567

Interarytenoid fold, hypertrophy of 295 Intracranial complication, following otitis media 104, 262

, otitic lesions 193

, pressure, effect of, on the sound-perceiving apparatus, 416

Intranasal conditions in various races $15 \mathrm{I}$ ,, disease and sexual excitement 245

, operations 95

," ," complications after

Intubation, complications after
$25 \mathrm{I}$

as an aid to tracheotomy $2 \mathrm{II}$

for croup 554

laryngeal $98, \mathbf{1} 47,254,569$

new tracheotomy tube 60

\section{K.}

Kerostomia 402

\section{L.}

Labyrinthine concussion $3^{8} 5$

, nerves, course of 391

,$\quad$ vertigo 216

Labyrinthitis, acute, following mumps 236

Laryngeal mirrors 157,255

, polyp $62 \mathrm{r}$

, sprays 235

,, stridor 134, 303, 308, 309

, tubercle, therapeutics of 554

Laryngectomy 82, 409, $57 \mathrm{I}$

Laryngitis-

desquamativa 570

exudativa $4 \mathrm{I} \mathrm{I}$

fibrinous 559

following intubation 147

hypertrophic 65

membranous, in absence of diphtheritic bacilli 570

rheumatic 145

sicca 292

singers', treatment of 459

treatment of, with erysimum 253

tubercular $69,350,472$

Laryngology progress in I, 30

research and clinical experience in $43 \mathrm{I}$

résumé of papers on $57 \mathrm{I}$

Laryngo-œesophageal disease 352

Laryngoscopy in children 278

Larynx-

abscess in $5 \mathrm{II}, 547$
Larynx (continued)-

amyloid tumours of $2 \mathrm{IJ}$

as an organ of speech 98

cancer of $57,99,350,519,553$

effects on, of measles 518

of leucocythemia $37 \mathrm{I}$

epithelioma of $29 \mathrm{I}, 57 \mathrm{I}$

extirpation of 3 I I

$$
\text { , ,, partial } 143
$$

fibro-sarcomatous tumours of 212

foreign bodies in $388,206,545$

growths in, recurrent 505

hæmorrhage of 149,253

intubation of 254,569

lupus of $64,211,255,359$

malignant disease of $97,142,195,209$,

$35^{2}$

occlusion of 256

cedema of 199,288

pachydermia of 503

papillomata of $142,194,211,35^{2}$

paralysis of 97,522

paresis of 357,504

pemphigus of 366

photography of $\mathbf{1} 45$

phthisis of 255

retrospect of $1897 * 30$

rheumatism of 99

sarcomata of 85

tuberculosis of $75,347,467,473,544$

155

$$
\text { guaiacol treatment of }
$$$$
\text { ," }
$$

tuberculosis of, pathogenesis and early evidence of 481

tuberculosis of, treatment of per vias naturales 507

tumours of, uncommon 293

$$
388 \text { removed by thyrotomy }
$$

ulceration of 356,544

urticaria of 522

vertigo of 520

Lepra of larynx, mouth and nose 285

Leucocythremia-

effect of, on larynx $37 \mathrm{I}$

," , trachea 371

Leucoplasia, buccolingual 623

Lingual Tonsil-

pathology of 547

phlegmonous inflammation of 624

Ludłwig's angina 269

Lupus-

and the X-rays 205, 308

antitoxin treatment of 504

Lupus of -

face 398

larynx $211,255,359$

nose I94, 360, 36r, 398

Lupus vulgaris, hot-air treatment of 245

Lymphangiectasis of floor of mouth 203 
M.

Macroglossia 93, 203

Malleo-incudal joint, subluxation of 556

Manometric flames, as a means of study. ing the vowels 254,389

Massage in deafness 260

Mastoid-

apparatus for operations on 198, 509, 512

cortical operation on 364

indications for operation on 217 opportune momi:at for i.icning the 621 percussion and ati-ci:lat:in:t oil 202 percussion of 217

Mastoid disease-

treatment of, with antistreptococcic serum $26 \mathrm{r}$

trephining of the mastoid for 261

Mastoid operations 21 7, 592 ", suppuration in a diabetic patient 217

Mastoidal empyema 452

Mastoidectomy, with complications 572

Mastoideocentesis $25^{8}$

Mastoiditis-

Bezold's 316

from middle-ear inflammation 420

Maxilla, superior-

osteomyelitis of $\mathrm{I} 54,204$

osteo-periostitis of 370

resection of 204

Maxillary sinus-

artificial opening in 369

cancer of 330, 332, 333

catarrh of 368

empyema of 370 , 391

operation on 177

pathology of 205

plugging 360

Measles, effects of, on larynx 518

Meatus, auditory-

cerebro-spinal fluid from 214

cholesteatoma of I 49

exostosis of, unusual case of $4 r_{4}$

foreign bodies in 258

obliteration of external, following otorrhcea 393

Membrana tympani-

inflammation of, from dental pulpitis 542

paracentesis of 215

perforations in 257,393

, diagnosis of 214

" treatment of, with tri. chlorace tic acid $26 \mathrm{I}$

rupture of 194,513

394,555

Meningitis 141, 407

deafness from 556

purulent 457
Meningococcus, in nasal secretion 407

Meyer Memorial, The $\mathbf{5 2 6}$

Microbes in normal nose 247

Middle ear-

inflammation of, acute 420

polypoid growths in 397

sarcoma of 464

Middle-ear disease-

complications of 453

phenomena dependent upon 90

suppurative 498,6 10

103, 262, 527

thyroid treatment of $46 \mathrm{I}, 537$

Mouth-

lepra of 285

tuberculosis of 387,402

Mouth and Pharynx, Diseases ofrésumé of cases of 33

Mumps- papers read on 33

followed by deafness 317

$$
, \text {, labyrinthitis } 236
$$

Mycosis pharyngis leptotricia 57 I

Myringitis-

acute 543

dry, chronic 59 r

hæmorrhagic 364, 591

sub-acute 502

N.

Nares, abnormal width of 250

Nasal

accessory cavities, diseases of 205 , sinuses, suppuration of 69 and ocular diseases, connection

between 208,564

atresia 206

bacteria, in health 124,248

bones, destruction of 398

bougies 96

clefts, congenital 245

cysts $272,358,55^{2}$

drainage tubes 96

fossa, neoplasm of 94

,, abnormal width of 564

hydrorrhœa 137,500

insufficiency 554

lupus $194,360,36 \mathrm{r}$

mucosa, irritation of 307

obstructions $25 \mathrm{I}, 303$

" epileptoid seizures from 564

obstructions, effects of removal of, 505

622 operative treatment of

polypi $96,309,388,505,508,514,545$

reflexes 75

respiration, measurement of 201 
Nasal (continued)-

secretion, meningo-coccus in 407

septum, abscess of 234

plints 386

stenosis 509, 546, 60 I

stones 206

syphilis 6I 4

tumour, tubercular 96

Naso-pharynx-

abscess of $5^{13}$

disorders of, affecting voice 198

fibromata of 388

foreign bodies in 284

membranous diaphragm of, congenital 507, 544

papilloma of 292

polypus of 206,404

sarcoma of 77,86

Neck-

branchial cleft in 136

swelling in 136

tumour in 135

ulceration of 363

Necrosis of -

inferior turbinal $67,132,554$

temporal 262

Neoplasms on vocal cords 4I 3

Nerve-

auditory, concussion of the 593

facial, paralysis of 262,555

hypoglossal, sensory fibres in 243

Nerves-

vagus and recurrent laryngeal, symptoms of pressure upon 475

Neuralgia, trigeminal, relieved by tur. binectomy 139

Neuritis, auditory, alcoholic 502 , peripheral, from exposure 555

Nodule, Singer's 353

Nodules in the tonsils 626

Nose-

accessory cavities of $563,565,593$

adeno-carcinoma of 95,602

and sexual apparatus I09

angioma of $\mathbf{2 4 5}$

aspiration of 387

foreign bodies in $94,153,207,208,617$

fracture of cartilage of 496

furuncle in, followed by general sepsis 387,405

lepra of 285

lupus of 398

microbes of the, in health 247

osteoma of 512,547

rodent ulcer of 363

sarcoma of 247

scleroma of 398

syphilis of 5 I4

tuberculosis of $25 \mathrm{I}$

tumours of $25 \mathrm{I}$
Nose and naso-pharynx, retrospect of $1897 r 26$

Notices $54,60,105,163,267,321,378$, $474,557,576$

Nystagmus, following the radical operation $55^{6}$

\section{o.}

Obstruction-

laryngeal, effect of, on chloroform anesthesia 409

nasal, operative treatment of 622

Occlusion of -

larynx 256

naso-pharyngeal space 250

Edema of-

glottis 3 I I

larynx 199

soft palate 306

Csophagoscopy, therapeutical use of 256,257

Esophagotomy 100, 315

Esophagus-

eucaine in affections of 314

extirpation of, partial 3 II

foreign body in 158

pressure pouches of 137,213

tumour of 466

Olfactometer 75

Optic aphasia $4 \mathbf{I} \mathbf{I}$

Orbit, osteo-periostitis of, in infant 370

Orthoform, as an analgesic $156,157,199$

Osteitis I44

Osteoma frontis 365

, of nose 512,547

Osteomyelitis of upper jaw 204

Osteo-periostitis, syphilitic $\mathbf{2 3 9}$

Otalgia 76

Otitic lesions, intracranial $1_{3}$

,, pyæmia 216, 420, 512

Otitis media -

acute, removal of tonsils for 400

chronic, dry 237,616

followed by occipital abscess 592

intracranial complications from 104

non-suppurative 77

post-scarlatinal 396

suppurative, hacteriology of 502

", complicationsof 262,421

" cure of, by removal of adenoids, 283

" following influenza 456

", operative treatment of $103,260,262,527$, 590

post-scarlatinal $3 \mathrm{I} 7$

,

sub-dural abscess from

treatment of 592 
Oto-laryngolugy, holncainc in 252

Otology-

during 1897321

papers on, read luring $18974 \mathrm{I}$

progress in 8

research and clinical experience in 435

Otorrhœa-

chronic, conservative treatment of $59 \mathrm{I}$

" effect of, on meatus 393

,, of long standing 397

, surgical treatment of 318

in children 454

Ozæna-

bacteriology of $\pi 46$

chronic, treated by massage 74

boric acid " 74

different forms of 403

following turbinotomy 288

treatment of-

by massage 74

by electrolysis $5 \mathrm{I} 4$

new methods for 246

with antitoxin 206,379

with lysol water $59 \mathrm{I}$

\section{P.}

Pachydermia laryngis 503, 570

Palate-

cleft, operative treatment of 462

hard, ulcers of $56 \mathrm{I}$

soft, adhesion of, to pharynx 292,296

,, cedema of 306

, paralysis of 65,93

,. paresis of 131,504

, perforations of 555

, pismentation on 194

Palsy, facinl, of utitic origin $62 j$

Papillomata of -

larynx 142, I95, 2I I, 352, 62I

recurrent 6 io

naso-pharynx 292

septum nasi 303

tonsil $\mathrm{I} 32,353$

uvula $47 \mathrm{I}$

Paracentesis of the membrana tympani 215

Paralysis-

abductor 219,289

arm 507,545

bulbar 561

diphtheritic 501

facial $218,262,502,623$

laryngeal $97,354,522$

palate $65,93,616$

pharyngeal 65

recurrent 142

vocal cord 65,133
I'arcinis of -

larynx 357, 504

soft palate $13 \mathrm{I}, 504$

Parosima, a case of 618

Parotitis 196,306

Pathology of -

acute otitis media 400

antrum of Highmore 205

atrophic rhinitis 244

cortical auditory centre 257,373

Graves's disease 315

lingual tonsil 547

sub-glottic region 553

Pemphigus of larynx 366

Perforations in membrana tympani 257, 393

treatment of, with trichloracetic acid 261

Perforation of soft palate, 555

Perichondritis of

auricle 397

larynx 356

nose 298

Perinstitis of forehead, syphilitic 297

Petro-mastoid, ciearing out the, for otitis media 237,616

Pharyngeal tonsil, chronic inflammation of 606

Pharyngectomy $57 \mathrm{I}$ catarrh, treatment of, by curettage 622

Pharyngitis, chronic 299

,, membranous, recurrent 55

,, rheumatic 625

," sicca 204, 292

Pharyngo-maxillary triangle, adenophlegmon of 403

Pharyngo-mycosis 354,503

Pharyngotomy, subhyoid i 56,466

Phary" transhyoid i 56

adhesion of soft palate to 62,292 , 296

cancer of 306

epithelioma of 447

paralysis of 65

polypus of 243

spasm of 144

stenosis of 292

tuberculosis of 243

simulating lupus 508

Phlebitis of jugular 512,547

,$\quad$ lateral sinus 148, 512, 547

Hhlegmon, sublingual 269.

,, of inferior turbinate 554

Phonation, remarks on 618

Phthisis, laryngeal 255, 569, 593

,, laryngo-pulmonary 298,569

Picric acid, for suppurative otitis 147

Pilocarpin, for labyrinthine vertigo 216

,$\quad$ for deafness $\mathbf{3} \mathbf{7}$ 
Plica vestibuli, and aspiration of the nose in breathing 387,403

Poisoning by antitoxin 305

Polypi of -

ear 206

epiglottis 210

larynx 624

naso-pharynx 206,404

nose $96,149,309,388,505,508$, 514,545

pharynx 243

Polypus removed by thyrotomy 559

Post-nasal growths 405

Presidential address 427, 594

Pressure-pouches of œesophagus $1_{37}, 213$

Pseudo-phthisis 504

Psoriasis, lingual and cutaneous 623

Ptosis 133

Pulpitis, dental, effect of, on ear 543

Pyæmia, otitic $216,420,512$

, of lateral sinus 547

\section{$\mathbf{R}$.}

\section{Radical operation-}

complications of 393

favourable course of 393,556

followed by nystagmus $55^{6}$

for chronic otorrhoea 397

,e obstruction in nasal sinuses 406 typical $4 \mathrm{II}$

Reflex, aural 225

Report, for $1 \$ 95$ and 1896 , on I)r. Kayser's Ear, Throat, and Nose Klinik in Breslan 592

Report of 11 orlind (irowthe Committe I 78,285

Repont, Ninth Annual. on Siteter: Out patient Department, in kingusters 590

Respiratory tract, upper, cliceases of, the to abnormal width of nasal fosse 564

Retrospect of $\mathbf{1} 897-$

Larynx 30

Mouth and Pharynx 33

Nose and Naso-pharynx 26

Rheumatism and tonsillitis 625

Rhinitis

$$
\text { of larynx } 99
$$

atrophic 244,249

,, formaldehyde in 515

caseosa, of long standing 593

fibrinous, and nasal diphtheria 492

following scarlet fever 516

hypertrophic, cauterization for 562 , 591

pseudo-membranous 621

sicca 292

vasomotor 239
Rhinolith $150,154,564$

with cherry-stone nucleur 564

Rhinology, progress in 6,26

,, research and clinica experience in 433

Rhinoplastic operation 560

Rhinoscleroma 504

Roentgen rays-

treatment with, of lupus 205,308

use of, in physiology of the voice 201

Rupture of the membrana tympani 194, 547

\section{$\mathrm{S}$}

Salivary calculus 242

Sarcomata of-

casserian ganglion 399

ear 464

larynx 85

nasal passages 247

naso-pharynx 77,86

nose 249

tongue 39

Scarlet fever and rhinitis 516

" followed by orbital abscess and ethmoidal suppuration 559

, with otitis 317

,, , septic:emia $3 \mathbf{I} 7$

Scleroma of nose and upper lip 398

Sclerosis, initial symptom of $3 \mathbf{r} 9$

,$\quad$ of the ear 554

Septicamia, following furuncle in nostril $3^{8} 7,405$

," with scarlet ferer 3 I 7

absecs of $234,55^{2}$

lilateral tumours of 495,505

heeding polyp of 249

cyst of 552

deformity of $25 \mathrm{I}, 39 \mathrm{~S}$

deviation of $55^{8}, 559,622$

dislocation of carlilage of $47 \mathrm{I}$

epithelioma of 509

hæematoma of $55^{2}$

lymphomatous tumours of $13 \mathrm{I}$

papilloma of 303

perforating ulcer of 399

perforation of 136

piece removed from 559

tubercular tumour of 249

tumour of 133

Sexual apparatus and nose 109

Sexual excitement and intracranial disease 245

Sigmatic dyslalia 349,353

Singer's nodule 353

, laryngitis 459

" lass of voice 569 
Singing lessons for deaf-nutes 624 Sinus-

frontal, probing the 201

, disease of $139,302,356$

," empyema of $207,246,301,307$

,$\quad$ exostosis of 297

, , retention cyst of 207

, suppurative disease of 246

lateral, in relation to tympanic antrum 230

, operative treatment of 573

," phlebitis of 148

," thrombosis of $316,318,418$, 486

maxillary, catarrh of 368

, operation on 177

, patholngy of 205

nasal, radical operation for obstruction in 406

, suppurations of 69

" surgical treatment of 404

petrosal, deep groove for 557

sigmoid, thrombosis of 418

," thrombo-phlebitis of 503

sphenoidal, surgery of 565,593

Sinusitis-

ethmoidal 510,546

frontal 95,239

maxillary 386

, with diverticula and partitions $6 \mathrm{I}_{5}$

with broncho-pneumonic complications $5 \mathrm{I} 3$

Smell, disturbances of 617

Statistics of-

diphtheria 305

diseases of ear, throat and nose 563

Stenosis-

bronchial 76

laryngeal 98

nasal 371, 509, 546, 60I

of air passages 410,412

pharyngeal 292

sub-glottic 74

tracheal 6I5

Stigmatismus 212

Stomatitis, diphtheritic 243

Streptococcus infection 486

Stridor, inspiratory, infantile 568

, laryngeal 303, 308, 309

, respiratory, infantile $\mathrm{I} 34$

Sublingual phlegmon 269

Subluxation of malleo-ir:cudal joint 556

Subglottic region, anatomy and physio. logy of 553

Suppuration-

aural I4, 103, 260, 418, 448, 453,498

cerebral 508

nasal 386, 559

Surgery of-

nasal sinuses 565
Surgery of -

sphenoidal sinus 565

Syphilis-

aural 160,215

inoculation of, by lunar caustic 205

laryngeal $5 \mathrm{I} 4$

nasal 514, 6I4

soft palate 296

tonsillar 89

Syphilitic labyrinthitis IOI

, periostitis of forehead 239,297

Syringe, laryngeal $6 \mathbf{I}$

\section{T.}

Temporal, caries of $262,507,508,545$

, cholesteatoma of 262

," necrosis of 262

," with deepsigmoid groove 557

Tensor tympani, reflex contraction of 395

Therapeutics of laryngeal tubercle 554

Thiosinamine, some uses of 104

Thrombo-phlebitis of sigmoid sinus 503

Thrombosis of-

lateral sinus $316,318,486$

longitudinal sinus 198

Thymus, enlargement of the 210

Thyroid cartilage, swelling over 289

, cyst IOI

", fever, following operations on goître 213

, treatment of middle ear disease $46 \mathrm{I}, 537$

Thyroidectomy for goître 213

Thyrotomy for-

epithelioma of vocal cord 506

growth below anterior commissure $55^{8}$

laryngeal tumour 388

cancer 553

papillomata of vocal cord 559

tumours of glottis 410

Tinnitus, treatment of 622

Tongue -

angio-neurosis of 93

excision of 241

sarcoma of 391

tuberculosis of 243

tumours of 62,243

Tonsillitis and rheumatism 625

", lacunar 400

", ulcero-membranous, chancri-

Tonsilsform 554

absorption of foreign substances by,200 angiomata of 243

as sources of ingress for infection $40 \mathrm{r}$

carcinoma of 242

chronic affections of 93,606

cystic degeneration of 545

enlargement of, after tonsillotomy 297 
Tonsils (continued) -

hypertrophy of $135,242,245,405$

malignant disease of 195,359

nodules in the 625

papillomata of $63,132,180,353$

place of, in the organism: 625

removal of, for acute otitis media 400

subpharyngeal cartilage of 141

syplititic infecion of 89

ulceration of 136,242

Tornwaldt's disease I 34

Trachea-

affected by leucocythæmia $37 \mathrm{I}$

foreign body in 76,570

plugging of, by a caseous gland 314

stenosis of 6 I 5

Tracheitis, membranous, without presence of diphtheritic bacilli 579

Tracheotomy 132, 387

for goître $57 \mathrm{I}$

for laryngeal papilloma 6II

for removal of foreign body from trachea 76

for removal of sub-glottic tumour 252 for tracheal stenosis 6 I 5

in children $211,314,611,615$

Tracheotomy tube, new 60

Transillumination as a diagnostic, fallacy of 245

Trephining the mastoid $26 \mathrm{r}$

Trichloracetic acid for perforations of membrana tympani 26I, 394, 555

Tubercular epiglottis 199,356

Tuberculosis-

laryngeal $6 \mathrm{r}, 347,467,472,473,48 \mathrm{r}$, $507,508,544$
treatment of dysphagia in 460

lingual 243

nasal 25I, 467

of mouth 387,402

pharyngeal 243

Tumour of-

auricle 622

brain 102, 104

ear, angio-sarcomatous 76

epiglot tis 133,184

glottis 510

interarytenoid 183

larynx 2 I I, 293, 388

,, fibro-sarcomatous 212

lip 297

neck 135

nose 251

" lymphomatous 31

,, tubercular 96

cesophagus 466

septum 133, 249, 495, 505

tonsil 135

Tumours, malignant, treatment of, with arsenious acid 621

Tuning-fork tests 258
Turbinate, inferior -

enlargement of 244

necrosis of $67,132,153$

phlegmon of 554

removal of 153,288

Turbinectomy I39, 153,288

Turbinotomy cautery 139

Tympanitis, acute, in a child 395

Tympanum, affections of, treated with the bougie 260

local anæsthesia for operations on 622 rupture of 547

\section{U.}

Ulceration of-

auricle I60, 215

epiglottis 199,544

larynx 356,544

neck 363

nose 363

palare $56 \mathrm{I}$

septum 399,467

tonsils 242

vocal cord $14 \mathrm{I}, 544$

Urticaria of-

larynx 522

pharynx 3II

Uvula -

epithelioma of 183

papilloma of $47 \mathrm{I}$

V.

Velar abscess 623

Velum palati, contractions of 624

Ventricle of larynx, growth within 470

Ventricle of Morgagni, prolapse of, 69 , 398

Vertigo-

aural 414

labyrinthine 216

laryngeal 354,520

Vestibule, relation to, of tympanic antrum, 232

Vocal band, disease of 68

Vocal curds-

agmination of secretion on, 348, 353 angiomata of 154

epitheliomata of $185,254,291,506$

fibromata of $356,358,468$

fixation of $132,289,351$

median position of 520

neoplasms on 413

papillomata of 559

paralysis of 65,133

paresis of 156

tumour of, for diagnosis 472

ulceration of $14 \mathrm{I}, 544$ 
Vocal lips, in chest and head registers I3I

Voice centre 412

Vowels, study of the 254,389

W.

Whooping cough and ear disease $25^{8}$ Wilhelm Meyer Memorial, unveiling the $\mathbf{5 7 7}$

\section{$\mathbf{x}$.}

$\mathrm{X}$ rays, use of-

in probing frontal sinus 370

, , laryngeal region 388

, physiology of deglutition 370

", treating lupus 205, 308

\section{ORIGINAL ARTICLES.}

Adenoid Vegetations, Complications following Extirpation of 276

Aural Reflexes 225

Baratoux's Electrical Laryngo-Phantom, Modified 233

Bilateral Abscess of the Septum Nasi 234

Cancerous Growth of Larynx, Case of 57

Cysts of the Floor of the Nose 272

Epithelioma (Primary) of the Antrum of Highmore 325

Epithelioma of the Middle Ear 342

Exostosis of External Auditory Canal 338

Exostoses, Aural 383

Labyrinthitis, Acute, following Mumps 236

Laryngeal Sprays, Caution in the Use of, 235

Laryngology, Rhinology, and Otology, Progress of $\mathrm{I}$

Laryngoscopy in Children 278

Ludwig's Angina, or Sub-lingual Phlegmon 269

Nasal Bacteria in Health 124

Nasal Reflex Neuroses, Etiology of 580

Naso.Pharyngeal Adenoids, Operation for, under Chloroform, followed immediately by Death 382

Nose and Sexual Apparatus, Relations between 109

Ozæna, Treatment of, by Antidiphtheritic Serum 379

Paralysis of the Abductor in Progressive Organic Disease 219

Priority of Claim to the Operation on the Antrum of Highmore combin. ing Temporary Opening in Canine Fossa and Opening in Nose 177

Recurrent Membranous Pharyngitis, of Nineteen Years' Duration $\mathbf{5 5}$

Suppurative Ear Disease, and its Relation to the Exanthemata I4

Supratonsillar Fossa, and its Affections I65

Tympanic Antrum, Anatomy of 230

Vaso-Motor Innervation of the Larynx 584

\section{SOCIETIES' MEETINGS, \&c.}

American Laryngological, Rhinological, and Otological Association 77, 594

Austrian Otological Society 393, 555

Belgian Otological and Laryngological Society 507, 544

British Laryngological, Rhinological, and Otological Association 185, 358,502

British Medical Association 267, 427, 475,526

Dutch Laryngo-Otological Society 73

Hungarian Laryngological and Otological Society $365,398,55^{8}$

International Medical Congress, Twelfth, at Moscow 69, 145, 200

International Otological Congress, Sixth, Notice of 557

Laryngological Society of London 60, I $31,178,285,350,466,576$

Société Française d'Otologie, de Laryn. gologie, et de Rhinologie 547, 6r4

Society of Laryngology, Otology, and Rhinology of Paris I47, 198, 237,389

Union of West German Throat and Ear Surgeons 386

Western Ophthalmological and Oto. Laryngological Association 378

\section{REVIEWS.}

Brandt-Klinik der Krankheiten der Mundhöhle, Kiefer, und Nase 265

Bussenius and Cossman-Das Tuberculin TR. Seine Wirkung und seine Stellung in der Therapie der inneren und ausseren Tuberculose 320

Gordon, H. L.-Sir J. Y. Simpson and Chloroform 162

Gould-The Year Book of Medicine and Surgery (1 898$) 378$

Heymann-Handbuch der Laryngologie und Rhinologie 51, 263, 523 
Holmes, T.-Benjamin Brodie 574

John Hopkins Hospital Reports-Gynæcology 320

Journal of Tropical Medicine 574

Manders, H.-The Ferment Treatment of Cancer and Tuberculosis 526

Moullin - The Treatment of Sarcoma and Carcinoma by Injections of Mixed Toxins 320

Power, D'Arcy-William Harvey 53

Sajous-Sajous' Annual and Analytical Cyclopedia of Practical Medicine for 1898,422

Spiess-The Use of Roentgen Rays in Rhinology 376

Stokes, Sir W. - William Stokes: His Life and Work 422

Weber, Hermann and F. Parkes. - The Mineral Waters and Health Resorts of Europe 525

Williams, W. P.-Diseases of the Upper Respiratory Tract: the Nose, Pharynx, and Larynx 42 I

\section{INSTRUMENTS.}

Acetylene Lamp (Sabrazes) 202

Endolaryngeal Mirror (Mermod) 255

French's Apparatus, Medifications of 553

Forceps for Laryngeal Tuberculosis (StClair Thomson) 266

Forceps for Naso-Pharyngeal Adenoids (StClair Thomson) 265
Forceps for Removal of Nasal Hypertrophies (Martin, M.) I 49

Forceps for Removal of Hypertrophied Tonsils (Furet, M.) 240

Galvano-Cautery Snare (Malen) 62I

Instrument for applying Silver Nitrate to Larynx (Cube) I46

Instrument for Curetting the Attic (Delie) 509, 545

Laryngeal Auto-Insufflator (Yonge) 363

Laryngeal Forceps (Lake) 575

Laryngeal Forceps (Whistler) I64

Laryngeal Forceps (Williams) 470

Laryngo-Phantom, Electrical (Grant) 300

Punch Forceps (Lake) 298

Snare for Throat and Nose Work (Lack) I80

Turbinotomy Cautery Point (Waggett) 267

\section{NEW PREPARATIONS.}

Tabloid Chemical Food 105

Tabloid Hypophosphites Compound 474

\section{BIBLIOGRAPHY.}

106 to $108 ; 130 ; 276 ; 321$ to 324 ; $337 ; 423$ to 425 


\section{NAMES OF AUTHORS.}

\section{A.}

Agar, M. 62, 356

Albers-Schönberg 205

Alderton 4I4

Alexander, A. 149

Alt, F. 257, 373, 416, $55^{6}$

Amyot, J. A. 150

Anderodias IOI

Anderson, H. B. 158

Annandale, T. 96

Ardénne 513

Arinstrong, G. E. 241

Armstrong, H. L. 244

Avellis, G. 568

\section{B.}

Baber, C., 137, 351

Ball, J. B. 62

Ballance, H. A. 486

Ballance, C. A., 193

Bar, L. 209, 62I

Barnet, L. E. 518

Barnett, J. E. S. 3 II

Barnick, O. 37 I

Baron, B. $35^{8}$

Barr, T. I02, 448, 452

Parth 307

Batten, F. E. 501

Baumgarten 559, 561

Bayer 314, 507, 544

Béault 203

Bell, J. 416

Bennett 357

Bérard 213

Berens, T. P. 418

Bergeat, E. 151, 205

Bergengrün, P. 285

Bergmiann 209

Bernhardt 624

Berthold 210
Besold, G. 569

Beuthen, H. 3I 5

Bezold 315

Biehl, C. 257, 394, 556

Bingham, G. A. 158

Bloch, E. 214

Bloebaum, F. 562

Boland 509, 546

Bonain 554, 623

Boncheron 554

Bond I 33,473

Bonnier, P. 391, 618

Bönninghaus, G. $15 \mathrm{I}$

Bottome, F. A. 569

Boulay 615

Bowen, J. J. 242

Brael 73, 76

Breitung, M. 94

Brindel 5 3,624

Bronner, A. IO3, 142, 295, 316

Brown, P. 604

Brown, R. H. 306

Browne, L. 359,549

Brühl, G. 420

Bryan, J. H. 94, 95

Burgher, H. 74, 75, 77

Burwinkel 205

Butlin, H. T. 137, 213, 357

Buys 400, 508, 509, $5 \mathrm{II}$, 545,546

\section{C.}

Carette 258

Carnot 244

Carruthers, S. W. 153

Cartaz 62I

Casselberry, W. E. 244, 269

Castex 202, 553
Chambers, G. 153

Cheatle, L. 464

Chiari, O. I 54, 210

Christy, T. C. 597

Cobbett, L. 304

Codd 569

Coffin 6or

Collet 617

Colman, W. S. 158

Coosemans 252, 509, 546

Costinin, A. 621

Courtade, M. A. 198

Cox, C. N. 606

Cozzolino 146

Craig, R. H. $5^{6} 3$

Crouzillac 155,624

Curtis, H. 459

Cuvillier 145

D.

Daly, W. H. 594

Day, E. W. 603

De Greift, 403

Delavan, D. B. 242, 244

Delie 509, 5I 2, 545, 554

Delsaux 507, 509, 511 ,

$512,544,545,547$

Delstanche 509, 5 I 2, 546,

547

Delstanche, Jun. 507, 545

De Mendoza, S. 622

Dench, E. B. 9c

De Santi, P. R. W. 296, 297

D'Iloore 420

Donald, W. M. 562

Donelan, J. 6r, I35, 155

Douglas, A. 153

Downe, W. 183

Doyen 213 
Names of Authors.

xix.

E.

Eagleton, W. P. 103

Ebstein, L。 256

Einhorn, M. 257

Elder, J. M. 242

Escat, E. 214, 547, 622

Etrévant, 156, 159

Eulenstein, H. 420

Ewing, F. C. 196

F.

Farlow, J. W. 252

Finck 555

Fleming, C. 97

Fongeral, H. 624

Fraenkel, A. 242, 518

Franklin, M. 306

French, T. R. I45

Freudenthal, W. 242

Friedrich 97

Frohmann, D. 368

Fullerton, A. G. R. 9 I

\section{G.}

Garel, J. 153, 552, 553

Garre 3 II

Gaudier 153, 2 I I

Gelle, G. 62I

Gerber, P. H. $5_{6} 3$

Gerhardt 93

Geyer, V. 253

Girard 204

Glasgow, W. C. 245

Gleitsmann, J. W. 93

Glover 147

Goldstein, M. A. 160, 21 5,338

Goodale, J. L. 200, 366

Gordon, H. L. 162

Goris 510, 546, 571

Gorodecki, H. 570

Gouguenheim, A. 211

Gradenigo 160, 215

Grant, D. I, 4I, I36, $185,194,233,235$, 236, 281, 300, 301, $347,348,349,352$, $353,359,364,468$, 502, 504, 554

Grayson, C. P. 245

Grimes, L. A. 570

Gruber, F. 215, 393 , 396,556

Grunert, K. 160

Guder 307

Guinard, A. 2 I 1
Guttman, J. 316

Guye $74,387,403$

\section{H.}

Halsted, T. II. 85,605 , 610, 612

Hajek 69, 205

Hamilton, B. 57

Hammerschlag 395, 397,

555,557

Hammond, L. I. 404

Harmer, L. 3I3

Hartman, J. H. 243

Hecht, H. 514

Hédon, E. $5^{84}$

Heerman, $5^{63}$

Heiman 216

Hektoen 306

Henderson 404

Hermary 253

Herzfeld, J. 369

Hennebert 42I, 507, 512, 545,547

Hessler 400

Hewlett, R. T. 466

Heymann $5 \mathbf{I}$

Hicquet 508

Hill, W. $63,64,354,365$

Hinkie, F. H. $3^{82}$

Hirsch, W. 243

Hollaender 245

Hoover, P. F. 103

Hopkins, F. E. 95, 245

Hopman 388

Hopmann 258, 410

Horne, J. 65, 131, 470, 473,481

Hovell, T. M. $45^{8}$

Huguet 545

Huiquet 509

Hultl 398,560

Hunt, J. M. 55, 492, 505

I.

Ischwall 206

Israi 366

J.

Jackson, G. 498

Jacobson 201

Jacquin 148

Jakins, P. 503, 542

Janquet 547

Jauhelevitch 216
Jauquet 510,546

Jessen, F. 401

Jollye, F. W. 317

Jones, H. E. 453

Jonnesco 257

Jordan, M. 369

Jurasz 519

K.

Kalmus 217

Kanthack, A. A. 285

Kayser, R. 200, 592

Kedel 245

Keller 258

Kelly, A. B. 272, $35^{8}$

Kerr, J. C. 82

Killian, G. 519

Klemperer, F. 520

Kocher, T. 57 I

Koppel 206

Körner, O. 217

Kossel, H. 305

Krebs 204

Krepuska 399

Kronenberg 388, 410

Kummell 308

L.

Labarre 509, 545

Lack, L. I $34,144,180$, 298, 303, 308

Lacoarret 623

Lacour, R. I56

Lacroix, 147, 199

Lake, R. I61, I77, 183, 2 I $7,230,283,298,356$, $383,385,386,467,544$

Lambard 5 I 2

Lane, W. A. 103

Lanffs 206

Lannois 553, 622

Lartail 573

Laurence 357

Laurens, G. 623

Lavrand 553, 554

Law, E. 354

Lawrence 69, 297, 471

Lederman 258

Logan, J. E. 610

Leland, G. A. 95

Le Marc Hadour 623

Lenzmann, 387, 402, 405

Lermoyez 198, 616

Lester, J. C. 259

Lewis, R. 93

Leyser 405

Tinia. $6 \geq 3$ 
Lichtwitz 149, 154, 156, 199, 202, 239, 391

Lieven, A. 514

Litchfield, W. F. 305

Lockard, L. B. 245

Lombard 206, 547

Longbotham, G. F. 314

Low, H. 317

Lowenstein 254

Lubet Barron 149

Luc I 48, $55^{\circ}$

Ludewig 318

Luzzati 217

M.

MacAlister, A. 92

McBride, P. 427, 520

Macdonald, G. 433

Macgregor, A. 305

Macintyre, J. 30, 219

McKee, A. B. 521

Mackenzie, G. H. 309, 514

Mackenzie, J. N. 109, 246

Malen 621

Malherbe, r98, 237, 616, 622

Maljutin, E. N. I56

Manasse, P. 411

Marage 254, 260, 376, 389

Marcuse, P. 207

Marsh, F. I86, 195

Martinez, E. 207

Martuscelli 21I

Mayer, E. 255

Mendel 554, 622

Ménière, E. 260

Mermod 255

Meyjes, P. 37o, 543, 580

Michelsen 75

Milligan, W. 26, 234, 246, $284,435,527$

Miot 555

Moll, A. C. H. 75, 622

Mongour 243

Morse, J. L. 305

Moses 389

Mounier 617

Moure, E. J. 246, 521, 553,623

Mouret 554

Muller, M. 207

Muller, R. 260

Munche, S. 4II

Murray, M. 255

Musehold I3I

Mygind, H. 379

Myles, C. 604
N.

Naguet 547

Neuenborn 387,412

Newman, D. 291, 292, 475

Nichols, J. E. 247

Noquet 513, 618

o.

O'Kinealy 405

Onodi, A. 4I2

Oppenheimer, S. 247

Ouston, T. G. 218

Owen, E. 462

P.

Packhard, F. 95

Panzer 395

Park, W. H., 124, 247, 248

Paterson 165, 179, I80

Paul, H. 304

Payne, F. D. 92

Pegler 67, 68, 131, 132, $136,352,471,496,505$

Pel 74, 75, 76

Permewen 466

Petersen, R. 278

Peyrissac 255

Phillips, W. C. 325

Pierce, N. H. 249

Plicque 243

Pluder, F. 625

Politzer 393, 397, 557

Polo 621

Polyak 398, 559

Poole, W. H. 564

Potter, F. 142, 195, 503

Power, D'Arcy 53

Preysing 249

Pringle, G. L. K. 261

Pynehon, E. 96

\section{R.}

Railton, F. C. 211

Raoult 554, 555, 564

Raugé 93

Reardon, T. 306

Reerink 249

Reid, StGeorge 194, 363

Reintjes 74

Rice, C. C. 249

Richards, G. L. 515

Richardson, C. W. 596

Richardson, W. L. 104
Rimini, E. 261

Robin, A. 622

Robinson, R. B. $35^{\circ}$, 351,472

Rodocanachi, A. J. 100

Roestal 250

Root, A. G. 89

Root, E. 564

Röpke 204, 207, 386, 406

Rosapelly 98

Rosenberg, A. 570

Rosenfeld 212

Rosenthal 305

Ross, G. F. 522

Roughton, E. 288

Rousseaux 512, 547

Rowe 370

Ryerson, G. S. 162

\section{S.}

Sabrazes 156, 199, 202

Sandford, A. 33

Sachs, R. 96

Saint Hilaire, M. 391

Saenger, M. 250, 564

Sarremone 554

Saurez de Mendoza 553

Schech 515

Scheier, M. 201, 370

Scheppegrell, W. 250

Schiff, A. 407

Schmidt, E. 99

Schutter 75

Schwartz 243

Seifert 564

Semon, Sir Felix, 292 , 293, 43I, 577

Semonsohn, M. 208

Sendziak, J. 276

Sharman 353

Sharp, A. X. 402

Shaw, C. E. 447

Shirley, E. L. 571

Singer 556

Sizenes 26r, 262

Snow, S. F. 598

Snyder, A. A. 100

Somers, L. E. 262, 625

Spencer, W. G. 62, 139, 185,302

Spicer, S. 65, 133

Spiess, G. 565

Stacke, L. 262

Starr, F. N. G. 572

StClair Thomson 290, 500

Stetter 590

Stewart 288

StGeorge Reid 502, 504 
Names of Authors.

xxi.

Stiel 208

Stillson, H. 256

Stillson, J. O. 572

Stoker, G. 363, 504

Sutcliff, E. H. 315

Symonds 142, 143, 291, 356,467

Syms, P. Ior

T.

Taptas 371

Tavel 203

Taylor 3 II

Tervaert, C. 74,76

Texier 615

Thiry 554

Theisen, C. F. 251

Thomas 573

Thompson, J. A. 88

Thorburn, J. D. 154

Thorne, A. 136, 298, 354,365

Thorner, M. 602

Tilley, H. 66, I4I, 289

Tissier P. 25I

Todd, C. $5 \mathrm{I} 6$

Toeplitz, M. 57 I

Tournier 622

Tousey, S. 104

Turnbull, L. 96
U.

Uchermann, V. 99, 145

Urbäntschitsch 395, 396, 397

v.

Vacher 157,614

Vali 560,561

Van Leyden 77

Vansant 407

Verco, J. C. 413

Vincent 240

Viollet, M. P. 239

Von Engelen 403

Von Navratil 365, 398, $55^{8}, 559$

Von Stein 413

W.

Wachenheim, F. L. 562

Waggett, E. 135, I39, I81, 291 , 342, 547

Walker 290

Walker, E. 157

Wallace, A. 100

Walsh, J. E. 562

Walsham, H. 292, 626

Weiss 262

Werthein $25 \mathrm{I}$
Whiting, F. 318

Wilkin, G. C. 342

Willcocks 182,292

Williams, A. L. 91

Williams, W. 144,470

Winckler, E. 565

Wingrave, W. 67,132 , 14I, 195, 299, 302, $358,359,364,505$

Winkle 209

Wishart, D. J. G. 251

Woodbury, F. 522

Woods, R. H. I4, 262

Woodward, J. F. 104

Worthington 69

Wright, J. 96, 124, 247 , 248, 57 I

Wullstein 157

$\mathbf{Y}$.

Yearsley, M. 225, 303, 46I, 537

Yonge, E. S. 157,363 , 460

z.

Zaalberg 509, 546

Zarniko 567

Zwaardemaker 75, 319

Zwillinger 398 